\title{
Efficiency of Using a Web-Based Approach to Teach Reading Strategies to Iranian EFL Learners
}

\author{
Elham Dehghanpour ${ }^{1} \&$ Mahmood Hashemian $^{1}$ \\ ${ }^{1}$ Department of Foreign Languages, Isfahan (Khorasgan) Branch, Islamic Azad University, Isfahan, Iran \\ Correspondence: Mahmood Hashemian, Islamic Azad University, Isfahan (Khorasgan) Branch, Isfahan, Iran. Tel: \\ 98-913-266-3269. E-mail: m72h@hotman.com
}

Received: July 8, 2015 Accepted: September 2, 2015 Online Published: September 5, 2015

doi:10.5539/elt.v8n10p30 URL: http://dx.doi.org/10.5539/elt.v8n10p30

\begin{abstract}
Applying new technologies with their effective potentials have changed education and, consequently, the L2 teacher role. Coping with online materials imposes the necessity of employing Web-based approaches in L2 instruction. The ability to use reading strategies in a Web-based condition needs sufficient skill which will be fulfilled if it is integrated in pedagogy. The main focus of the present study was to investigate the efficiency of teaching reading strategies in a Web-based condition to Iranian EFL learners. Thirty L2 learners at upper-intermediate level from an English institute in Isfahan were selected as the experimental group. The group received a 20-hr reading strategy training in Web-based condition. Participants were taught 4 general reading strategies which were practiced through 3 stages of cognitive theory: cognitive, associative, and autonomous proposed by Anderson (1993). The instruments included a pre/posttest of hypertext reading comprehension, a pre/posttraining questionnaire for assessing the participants' familiarity with general reading strategies, a pre/posttest of reading comprehension, and an attitude questionnaire towards Web-based reading strategy instruction. Findings indicated that after reading strategy program, the participants' frequent usage of each reading strategy increased significantly and, consequently, they performed better at the reading tasks in Web-based and conventional conditions. Furthermore, the group had positive attitudes towards Web-based reading strategy instruction.
\end{abstract}

Keywords: reading strategy, hypertext reading strategy, hypertext, note-taking strategy, inferring strategy, context clues, skimming

\section{Introduction}

The widespread use of Web-based approaches in instruction makes learning and teaching via the Web something new and a controversial issue in education (Ferdig, 2005). As an educational tool, technology offers a number of applications in and outside the classroom. The application of computers in teaching reading "is an important and essentially unexplored field" (National Reading Panel, 2000, p. 23). Additionally, Web-based environments have been widely supported by research in L2 reading because they promote active learning. According to Schmare-Dobler (2003), L2 learners' strategies usage in reading printed texts highlight obvious similarity with those they apply while reading the hypertext. Research shows that L2 learners apply a number of strategies during hypertext reading through the Internet. These strategies consist of related nodes, skimming strategy, note taking by hand, summing the information up, and relying upon former knowledge.

Although reading hypertext seems to be a requirement in fulfilling academic success for L2 learners, little attention had been drawn to its importance. Cunningham (1999) explained some reasons for supporting the importance of integrating the Internet into pedagogy. First, the Internet makes a condition for individual learning as needed. Second, it is considered as a practical medium for improving learning skills. Finally, it provides a vast amount of information in every field.

In a Web-based condition, L2 students are more interested and motivated to learn English because it presents various tools to improve reading skills. Students can use online dictionaries; they can check the pronunciation of unfamiliar words; they can find a plethora of reading texts according to their levels, needs, and interests; they can check the results of the exercises after they are done and other variable like font size, color, and type that can influence their learning process. Research shows that learners generally have a positive opinion towards L2 reading strategy instruction via a Web-based condition. 
However, in online traveling, L2 learners face many texts and media, but because of lacking useful reading strategies, they just skip the reading texts and divert their attention towards the entertainments; besides, difficulty of hypertext reading (i.e., the pages provided on the different nodes of the hyperlink) in comparison with linear text reading makes it more challenging for L2 learners because hypertext requires heavier cognitive strategy than linear reading, meaning that the reader must do different tasks at the same time: as the reader, he or she must know how to find the information, decide how to follow the next steps, and keep the previous track as he or she progresses through different nodes of the network (Keep, McLaughlin, \& Parmer, 2000). This is also a problem most L2 learners face at upper-intermediate level since they know enough vocabulary knowledge, but because of unfamiliarity with appropriate reading strategies, they fail in comprehending the author's intended meaning and performing the reading task. In addition, the conventional mode of instructions for teaching reading comprehension makes the process of reading a futile endeavor because teachers generally assess students' reading competence by considering their performance of reading tasks and, therefore, the long process involved in completing the tasks may be neglected.

The incorporation of technology into the education, particularly for Iranian L2 learners, promotes the importance of investigating its impact on improving learning and teaching. There are few studies on the effect of Web-based programs on teaching reading strategies. To the best of the researchers' knowledge, almost no research has been carried out on the effect of a Web-based condition, especially on training reading strategies to Iranian EFL learners and comparing the reading comprehension process in different modalities of instruction. Additionally, there has been little analysis of the effect of Web-based instruction on L2 students' reading comprehension. Thus, in our study, the influence of teaching reading strategies in a Web-based condition on L2 learners was tested to describe the reading comprehension process.

\section{Literature Review}

\subsection{Reading Comprehension}

According to Vaughan (1984), reading is the ability to understand the writer's intended meaning. Thus, recently the attention on the nature of reading shift "from a focus on the product of reading (such as a score on reading comprehension test) to an emphasis on determining the strategies that readers use in various reading contexts" (Anderson, 1991, p. 466). Dubin and Bycino (1991) described reading as a conscious process in which readers' background knowledge plays a key role in comprehending the text intended meaning. Nevertheless, some texts need a long involved process, particularly for L2 learners at intermediate level (Coady, 1997). Such complex texts highlight the requirements of applying appropriate reading strategies (e.g., scanning for detailed information), since a lack of vocabulary and grammar knowledge causes the process of reading more challenging and time- consuming for lower levels (Paran, 1996).

\subsection{Learning Strategies}

Learning strategies are those processes that individuals consciously do to make a breakthrough in reading comprehending. Skilled L2 learners know how to think, what the requirements of a task are, and the capability to use the appropriate strategy in order to accomplish a task and strengthen their own learning.

Researchers have commonly investigated what kind of reading strategies L2 learners utilize in the reading process (e.g., Chinwonno, 2001; Huang, Chern, \& Lin, 2009; Lin \& Chen, 2006) and have found out the extent of their influence on L2 learners' reading comprehension. Several reading strategies have proved to be influential in advancing L2 learners' reading comprehension (Anderson, 2003; O'Malley \& Chamot, 1990; Oxford, 1990, 2001), which include cognitive strategies such as repeating what one has learned, identifying and applying regular patterns (i.e., identifying core sentences), as well as getting main ideas quickly by skimming and scanning texts. In Oxford's (1990) definition, "learning strategies are operations employed by the learner to make learning easier, faster, more enjoyable, more self-directed, more effective, and more transferable to new situation" (p. 8). She proposed another system of reading strategies in which she identified two types of reading strategies: (1) Direct strategies that consist of cognitive strategies to understand the language and compensation strategies in order to substitute for appropriate language in spite of language gaps, and (2) indirect strategies that include metacognitive strategies to organize the learning process, affective strategies to control emotions, and social strategies to collaborate learning.

\subsection{General Reading Strategies}

General text reading strategies refer to "the comprehension processes that readers use in order to make sense of what they read. This process may involve skimming, scanning, guessing, recognizing cognates and word families, reading for meaning, predicting, activating general knowledge, making inferences and separating main 
ideas from supporting ideas" (Barnett, 1988, p. 10). L2 research on learning strategies indicates the fact that learners strengthen their reading comprehension skill by applying general reading strategies.

\subsection{Web-Based Approaches}

The huge variety of information available online makes it of high interest, easily available, and exploratory learning for L2 learners at all levels, and it can be a valuable resource for reading programs. Teaching and learning language can easily be enriched by the Internet. Due to the fact that the common language on the Internet is English, it can be the best resource for L2 teachers and learners (Krashen, 2003). Coiro (2003) indicates that the iterance of the Internet in instruction means that new ways of teaching and learning will change L2 learners' ability in reading comprehension.

According to Konishe (2003), easy access to authentic materials from the Internet makes teaching reading comprehension more effective. The process of interacting with electronic texts requires particular "skills and abilities beyond those required for the comprehension of conventional, linear print" (RAND Reading Study Group, 2002, p. 14). According to Coiro (2003), the Internet makes it possible to interact with new reader elements (e.g., new types of background knowledge, new purposes or motivations, high-level metacognitive skills), new text formats (e.g., hypertext and interactive multiple media that require new thought processes), and new activities (e.g., publishing multimedia projects, participating in online synchronous exchanges, verifying credibility of images). Leu (2002) observes that, "the Internet has entered our classrooms faster than books, television, computers, the telephone, or any other technology for information and communication" (p. 311).

Integrating this new convention in the instruction emphasizes the need for thoroughly inspecting its influence on reading comprehension. Although the readily available literature on reading comprehension is considerable in order to investigate how learners comprehend the text, there is not sufficient information of learners' performance on hypertext reading comprehension (Aebersold \& Field, 1997, Anderson, 1991; Bernhardt, 1991; Grabe, 1991, 1999, 2009; Schwartz, 1984; Wolf, 1993a, 1993b). According to Corio and Dobler (2007), "little empirical evidence has been gathered, particularly among adolescents, to support the claims that printed and digital texts are distinctly different media requiring different cognitive processes" (p. 214).

The new formats of various contexts presented via the Internet indicate the different ways of reading comprehension. As Chifari et al. (2010) argue, "this situation highlights a rapid change in the nature of reading so that the online domain requires a different reading literacy from traditional ones and change of perspective in the dynamics of reading comprehension" (p. 491).

\subsection{Teacher Role}

Application of Web-based learning programs necessitates the emergency of clarifying the new roles of teachers and students. Shelton, Lane, and Waldhart (1999) claim that L2 teachers should act like facilitators, rather than distributors of new knowledge to their students. It is essential for a Web-based teacher to be a facilitator. Easton (2003) indicates that Web-based teaching is not about "putting up a Website or turning one's lectures into text and then stepping back" (p. 89) because this approach has no effect on learning. Wallace (2003) described the role of the Web-based teacher in which communication and interaction among the teacher and students is in center.

Salmon (2000) introduced an approach for teaching and learning in Web-based condition that includes five elements: availability, network socialization, interaction, elevating knowledge, and, professional development. Berg and Collins (1995) described the teaching qualification in a Web-based environment as writing skills, technical knowledge, virtual world construction, and supporting students in virtual communication. Wallace (2003) illustrated some basic tasks for the Web-based teacher: materials developer, communication with students, providing students with feedback, and evaluating their progress. She emphasized that stimulating class discussion activities and presenting lecture are essential in a Web-based condition. Berge and Collins (1995), Paulsen (1995), and Mason (1991) illustrated three key roles for teachers in a Web-based condition: (1) managing the training course, (2) establishing communication, and (3) developing creativity in ways of teaching.

Leu et al. (2004) state that it is challenging for L2 teachers to guide their students through Web-based environments because they are richer and more complex than the printed materials. These new environments make richer and more challenging opportunities for L2 students/teachers. There is a common question among L2 teachers: Whether the new literacies are "traditional skills being used in new environments" (Boling, 2008, p. 90).

\subsection{Hypertext Reading Strategy}

According to Salmeron, Canas, Kintsch, and Fajardo (2004), hypertext reading strategy is "the decision rule that 
a reader follows to navigate through the different nodes of a hypertext" (p. 5). A new way of reading is required for reading hypertexts in contrast to standard linear texts. A text had typically a linear format in which there is one way to progress through the text. Readers should start at the beginning of the text and continue to the end. However, information in hypertexts is presented in a semantic network in which all the sections of the text are connected to each other.

Chavangklang (2008) investigated the effect of call reading strategy training of Thai collage EFL learners on hypertext comprehension. This study applied tree-stage L2 cognitive theory (Anderson, 1999) for teaching general and hypertext strategies. It was found that participants performed significantly better at reading tasks after receiving a CALL-based program.

Dail (2004) found out that $10^{\text {th }}$-grade English L2 learners who were studying arts applied two strategies while reading via the Internet: Hypertext strategy students applied a number of strategies when reading the hypertexts. The two strategies were (1) hypertext reading strategy including navigation strategy and scrolling the pages, and (2) general strategies consisting of note taking by hand, summing the information up, skimming strategy, and referring to previous knowledge.

The above review on hypertext reading strategies indicates that L2 students utilize general text reading strategies that include cognitive and metacognitive strategies to read hypertexts along with navigational strategies (Anderson, 2003; Dail, 2004; Ganderson, 1998; Konishi, 2003).

\section{Research Methods}

\subsection{Participants}

The participants were 30 out of 42 Persian-speaking students who were selected in line with their scores on the Oxford Placement Test (OPT, Allen, 1992) in a language school in Isfahan, Iran. The participants were 15-18 years old and all were female. They were identified to be at upper-intermediate level. They all had more than 3 years of experience in using computers and the Internet for studying and entertainment goals. The reasons for selecting the upper-intermediate level were that, firstly, such group was a comparatively large number of L2 learners. Secondly, the lower level may not have been able to employ the reading strategies effectively to comprehend the hypertexts because they have a limited knowledge of grammar and vocabulary to comprehend hypertext; thus, more time and effort may be needed in terms of applying L2 reading strategies.Thirdly, advanced groups have already made up the necessary knowledge for appropriately applying L2 reading strategies; therefore, they may not need to participate in a training program. Lastly, the upper-intermediate learners are more interested and motivated to achieve academic success. All the participants were assigned to 1 experimental group in order to limit the (possible) effect of other variables on the results of the study. The experimental group was exposed to explicit training through a Web-based condition. A communicative approach with an emphasis on real communication was followed in the class. The teaching methodology included consciousness-raising tasks using a text from the Internet, followed by teacher-to-student discussions about the applied strategies. The participants were required to explain and verbalize their employed strategies.

\subsection{Procedure}

This study was based on the cognitive theory proposed by Anderson (1993), according to which L2 learning proceeds through three stages: Cognitive, associative, and autonomous stages that were practical for reading strategy training in our study. The stages of note taking, skimming, and inferring, and using context clues of Anderson's cognitive theory were applied in this study to teach the participants to apply the reading strategies.

At the outset of the study, a homogenizing OPT test was given to the learners to select a comparable sample from among 42 learners who were studying English at a language school in Isfahan, Iran. The sample was assigned to 1 experimental group. The participants followed the reading strategies training for 20-hr; they attended classes twice a week for about 2-hr each session. The teaching process started with note taking, skimming, and inferring, and using context clues carried out in the Web-based condition via the three phases of Anderson's cognitive theory (1993): The cognitive stage was the first stage of the program: The teacher explicitly explained about the strategies (e.g., skimming) and how to use such strategies. The participants were asked to verbalize and apply the reading strategies to a reading task after the training. The participants in the associative stage (i.e., the second stage) completed the tasks independently and practiced for fluency. They used each reading strategy in reading the hypertexts. In this stage, they were supported by the teacher when they made a mistake in completing the tasks. And, the participants in the autonomous stage (i.e., the third stage) were skilled enough to apply all the reading strategies independently for reading the hypertexts, and they independently completed the practice.

The data were collected through the following methods: To conduct the study, firstly the OPT was used in order 
to homogenize the participants. Secondly, pre/posttraining questionnaires, partly adopted from Anderson (2002), was applied. The questionnaires had 10 questions asking about how frequently the participants used reading strategies in comprehendig the hypertexts. The questionnaires were on a 5-point Likert scale: 1 (I never do this) and 5 (I always do this).

Next, to examine the effect of the program on comprehending the hypertexts, the tests were taken from the following Website: www.agendaweb.org. The tests contained three passages followed by three questions, which took $30 \mathrm{~min}$ to complete. The pre/posttests of the hypertext reading were administered in a Web-based condition. The participants were required to read the passage from the Website but answer the questions on the paper.

At the outset of the treatment, a paper-based pretest was administered to the participants in the traditional condition. The purpose of the pretest was to properly assess the learners' achievement in reading comprehension. The pretest was taken from the following Website: www.toefl.com. The test consisted of three readings, followed by five multiple-choice questions. It took $50 \mathrm{~min}$ to complete the test. The scores from the pretest were used for comparing with the scores from the posttest. After the treatment, a posttest was completed by the participants. The posttest was taken from the same Website. The level of both the pretest and posttest were appropriate for upper- intermediate level. The objective of the tests corresponded to the objectives of the reading strategies.

Finally, the participants were required to simply answer to an open-ended questionnaire regarding the effectiveness of the Web-based condition on learning strategies and their attitudes towards the training. The questionnaire was adopted from Soonthornmanne (2002) and was slightly modified to conform to the objectives of the study.

\section{Findings}

\subsection{Findings from Hypertext Reading Comprehension}

For analyzing the three sets of the scores in this study, a paired samples $t$ test was used. Table 1 displays the descriptive results of comparing the pretest and the posttest of the sample:

Table 1. Descriptive statistics for comparing pretest and posttest scores of reading comprehension under the hypertext condition

\begin{tabular}{lllll}
\hline & $N$ & Mean & Std. Deviation & Std. Error Mean \\
\hline Pretest & 30 & 4.96 & 1.62 & .29 \\
Posttest & 30 & 6.30 & 1.74 & .31 \\
\hline
\end{tabular}

Table 1 shows that the participants' mean score on the pretest $(M=4.96)$ was less than that of the posttest $(M=$ 6.30). In order to see if the difference was significant, Table 2 should be consulted:

Table 2. Results of paired samples $t$ test for comparing pretest and posttest scores of reading comprehension under the hypertext condition

\begin{tabular}{|c|c|c|c|c|c|c|c|c|}
\hline & \multicolumn{5}{|c|}{ Paired Differences } & \multirow{3}{*}{$t$} & \multirow{3}{*}{$d f$} & \multirow{3}{*}{$\begin{array}{c}\text { Sig. } \\
\text { (2-tailed) }\end{array}$} \\
\hline & \multirow[t]{2}{*}{ Mean } & \multirow{2}{*}{$\begin{array}{c}\text { Std. } \\
\text { Deviation }\end{array}$} & \multirow{2}{*}{$\begin{array}{l}\text { Std. Error } \\
\text { Mean }\end{array}$} & \multicolumn{2}{|c|}{$\begin{array}{l}95 \% \text { Confidence Interval of } \\
\text { the Difference }\end{array}$} & & & \\
\hline & & & & Lower & Upper & & & \\
\hline Pretest-Posttest & -1.33 & 1.74 & .31 & -1.98 & -.68 & -4.17 & 29 & .000 \\
\hline
\end{tabular}

As shown in Table 2, there was a significant difference between the pretest $(M=4.96, S D=1.62)$ and posttest scores $(M=6.30, S D=1.74), t(29)=-4.17, p=.000$ (two-tailed).

\subsection{Findings from the Questionnaire}

To find out whether there was a noticeable change in the degree of frequency of the participants' reading strategies usage in comprehending the hypertexts prior to and after the treatment, a paired samples $t$ test was run. 
As shown in Table 3, all the subsections were separately compared:

Table 3. Descriptive statistics for comparing the pretraining and posttraining questionnaire data

\begin{tabular}{lllll}
\hline & $N$ & Mean & Std. Deviation & Std. Error Mean \\
\hline Note Taking - Pretraining & 30 & 7.83 & .59 & .10 \\
Note Taking - Posttraining & 30 & 8.00 & .00 & .00 \\
Skimming - Pretraining & 30 & 8.20 & 5.00 & .91 \\
Skimming - Posttraining & 30 & 14.23 & 2.32 & .42 \\
Inferring - Pretraining & 30 & 1.23 & 2.09 & .38 \\
Inferring - Posttraining & 30 & 2.60 & 2.52 & .46 \\
Context Clues - Pretraining & 30 & 3.93 & 2.54 & .46 \\
Context Clues — Posttraining & 30 & 6.93 & 1.70 & .31 \\
Total — Pretraining Questionnaire & 30 & 21.20 & 5.96 & 1.08 \\
Total - Posttraining Questionnaire & 30 & 31.76 & 4.43 & .80 \\
\hline
\end{tabular}

A more detailed look at the figures presented in the four sections of the questionnaire - and in the questionnaire as a whole - differences could be seen between the participants' frequency range of using reading strategies in comprehending the hypertexts. However, to find out whether the differences provide statistically meaningful data or not, one needs to look down the Sig. (2-tailed) column in Table 4:

Table 4. Results of paired samples $t$ test for comparing the pretraining and posttraining questionnaire data

\begin{tabular}{|c|c|c|c|c|c|c|c|c|}
\hline & \multicolumn{5}{|c|}{ Paired Differences } & \multirow{3}{*}{$t$} & \multirow{3}{*}{$d f$} & \multirow{3}{*}{$\begin{array}{c}\text { Sig. } \\
\text { (2-tailed) }\end{array}$} \\
\hline & \multirow[t]{2}{*}{ Mean } & \multirow{2}{*}{$\begin{array}{c}\text { Std. } \\
\text { Deviation }\end{array}$} & \multirow{2}{*}{$\begin{array}{l}\text { Std. Error } \\
\text { Mean }\end{array}$} & \multicolumn{2}{|c|}{$\begin{array}{c}95 \% \text { Confidence Interval of } \\
\text { the Difference }\end{array}$} & & & \\
\hline & & & & Lower & Upper & & & \\
\hline Note Taking & -.16 & .59 & .10 & -.38 & .05 & -1.54 & 29 & .13 \\
\hline Skimming & -6.03 & 4.99 & .91 & -7.90 & -4.16 & -6.60 & 29 & .000 \\
\hline Inferring & -1.36 & 1.95 & .35 & -2.09 & -.63 & -3.82 & 29 & .001 \\
\hline Context Clues & -3.00 & 2.58 & .47 & -3.96 & -2.03 & -6.35 & 29 & .000 \\
\hline $\begin{array}{c}\text { Total } \\
\text { Questionnaire }\end{array}$ & -0.56 & 6.30 & 1.15 & -12.91 & -8.21 & -9.18 & 29 & .000 \\
\hline
\end{tabular}

Because the $p$-value is greater than the alpha level $(.13>.05)$ for the not-taking subsection of the questionnaire, it could be argues that the difference was less marked between the participants in applying this strategy in the pretraining $(M=7.83, S D=.59)$ and posttraining $(M=8.00, S D=.00)$ questionnaires, $t(29)=-1.54$.

As to the skimming strategy, the frequency range of reading strategy use of the participants in a Web-based condition underwent significant changes because the $p$-value under the Sig. (2-tailed) column in front of this strategy is .000 , which is less than 0.05 . A substantial change in the degree of frequency among the participants towards the use of inferring and using context clues strategies in the pretraining and posttraining questionnaires were also observed due to the fact that the $p$-values for these two strategies are .001 and .000 , respectively.

Finally, considering the whole questionnaire as a composite measure, the participants' familiarity and usage of reading strategies in the pretraining questionnaire $(M=21.20, S D=5.96)$ were significantly different from their familiarity and usage in the posttraining questionnaire $(M=31.76, S D=4.43), t(29)=-9.18, p=.000$.

\subsection{Findings from the Reading Comprehension Test}

The third research question of the current study was formulated to investigate whether reading strategy training in a Web-based condition enhances L2 learners' reading comprehension skill. To this end, a paired samples $t$ test 
was applied again. Table 5 displays the descriptive statistics for this analysis:

Table 5. Descriptive statistics for comparing pretest and posttest scores of the paper-based test

\begin{tabular}{lllll}
\hline & $N$ & Mean & Std. Deviation & Std. Error Mean \\
\hline Pretest & 30 & 9.86 & 2.47 & .45 \\
Posttest & 30 & 10.83 & 2.74 & .50 \\
\hline
\end{tabular}

It can be seen that the participants' mean score on the posttest $(M=10.83)$ is larger than that of the pretest $(M=$ 9.86). To see whether the difference is statistically meaningful, one should look at the Sig. (2-tailed) column in the Table 6:

Table 6. Results of paired samples $t$ test for comparing pretest and posttest scores of the paper-based test

\begin{tabular}{|c|c|c|c|c|c|c|c|c|}
\hline & \multicolumn{5}{|c|}{ Paired Differences } & \multirow{3}{*}{$t$} & \multirow{3}{*}{$d f$} & \multirow{3}{*}{$\begin{array}{c}\text { Sig. } \\
\text { (2-tailed) }\end{array}$} \\
\hline & \multirow[t]{2}{*}{ Mean } & \multirow[t]{2}{*}{ Std. Deviation } & \multirow[t]{2}{*}{$\begin{array}{l}\text { Std. Error } \\
\text { Mean }\end{array}$} & \multicolumn{2}{|c|}{$\begin{array}{c}95 \% \\
\text { Confidence } \\
\text { Interval of the } \\
\text { Difference }\end{array}$} & & & \\
\hline & & & & Lower & Upper & & & \\
\hline Pretest-Posttest & -1.33 & 1.74 & .31 & -1.98 & -.68 & -4.17 & 29 & .000 \\
\hline
\end{tabular}

Given the fact that the $p$-value is less than the significance level $(.04<.05)$, we can conclude that the difference between the participants' pretest scores $(M=9.86, S D=2.47)$ and their posttest scores $(M=10.83, S D=2.74) t$ $(29)=-2.09$ in the paper-based condition is significant.

\section{Discussion}

As mentioned earlier, there has been little research on the effect of a Web-based program on the reading strategies training on L2 learners' hypertext reading comprehension. As far as the background to the study supports, most previous research investigated whether teaching reading strategy (i.e., in a paper-based format) would increase students' reading comprehension. Some other studies either compared the effects of teaching reading strategies via the Internet (Theodorou, 2006) or in a traditional instruction.

Other studies (Kang, 2000; Singhal, 2001; Theodorou, 2006) investigated whether students taught via a Web-based program had positive attitudes/opinion towards learning in such a condition. Several researchers (e.g., Aydin, 2002; Slate, Manuel, \& Brinson, 2002; Usun, 2003) also investigated the attitudes of undergraduate and graduate L2 students towards Internet-based learning. Their findings showed that the students generally had positive attitudes towards Web-based English learning/teaching. It is, therefore, difficult to find enough supporting research in the field of Web-based training for the present study in order to support its effectiveness.

This study initially investigated the effect of a program on hypertext comprehension, and it was secondly was an attempt to gain deeper insights into L2 learners' frequent use of reading strategies in a Web-based condition, and the third goal of this study was to find out the (possible) influence of instruction on the reading comprehension skill, and the final goal was to investigate the participants' self-assessment and attitudes towards the program.

Apropos of the first purpose of the study, a more detailed analysis of the pretest and posttest scores showed that Web-based reading strategies training to L2 learners is an efficacious method of helping them improve their hypertext reading comprehension. The results of the first aim of the study are in line with the findings of previous research (Anderson, 2003; Chou, 1992; Ganderson, 1998; Namphadorn, 2007; Simthamnimit, 2004; Suwanabubpha, 2006; Thanasuntornrerk, 2004).

The findings related to the second aim of present study revealed that the training provided by the teacher contributes to a higher frequency of reading strategy usage in the hypertext condition. In order to find out whether the number of the points for each reading strategy was because of the training, the data obtained from each reading strategy was analyzed separately, and the achievements of each subsection was briefly explained. 
As for note-taking strategy, we can conclude that there was not a substantial difference between the application of this strategy in the pretraining and the posttraining questionnaires. The findings revealed that the participants applied this strategy before the training. Under this circumstances, it can be justified that they were familiar with note-taking strategies because the note-taking strategy is commonly applied in low-level proficiency.

According to the results obtained from pretest and posttest of the skimming strategy, the frequency of applying this strategy by the participants underwent significant changes. This is due to the fact that they found this strategy useful in recognizing the main idea of the reading texts quickly. The outcomes of this section correlate well with the results by Chou (1992) who found out that the learners had applied the skimming strategy after the treatment in order to progress through the hypertexts.

Regarding the inferring subsection, the findings show that the participants' application of this strategy in the pretraining and the posttraining questionnaires were significant, too. Hence, one could conclude that the participants' use of this strategy in hypertext reading comprehension increased remarkably after the training.

Considering the findings related to the context clues subsection, it can be argues that the participants improved in practicing how to apply this strategy effectively (e.g., guessing the meaning of a new word without looking up in a dictionary).

The above findings of the general reading strategies (e.g., skimming and context clues) support the findings by Anderson (2003) in which the researcher concluded that the learners had employed general reading strategies (i.e., cognitive strategies) that include skimming and context clues to read the hypertexts. The findings are also consistent with the results by Ganderson (1998) and Dail (2004) who indicated that the learners had used general and hypertext reading strategies like skimming, navigation strategies, and context clues, to read the hypertexts.

Compering the results of each section separately, we can see that there was a slight difference in the degree of frequency of the participants' application of these strategies. To sum up, inferring strategy was difficult for the participants in comparison to other strategies. Suggesting longer and more complicated lessons can improve L2 Learners' comprehension. Moreover, persuading L2 students to practice and utilize this strategy extensively will promote their familiarity.

Finally, considering the whole questionnaire as a composite measure, the achievement showed a high frequency of the participants' application of reading strategies in comprehending the hypertexts. In a nutshell, this lesson was very useful in improving hypertext reading strategies.

The third focus of the present study was on the effect of training on the participants' reading comprehension skill. Whereas the statistics showed that the participants' reading comprehension scores were not considerably high when they received the treatment in a Web-based condition, a rapid level of improvement took place in their posttest. The results of this study support to the ones by Simthamnimit (2004), Suwanabubph (2002), and Naphadorn (2007) that revealed that the learners were able to do better in reading comprehension after they had learned the reading strategies through CALL lessons.

To recap the participants' attitudes towards the Web-based program, they mostly had positive opinions towards the instruction. The reasons that they gave support the results of the current study. The findings as to the participants' opinions are in line with the findings in Kang (2000), Singhal (2001), and Theodorou (2006) in which the learners taught via a Web-based program had positive attitudes towards learning in such an environment. Studies investigating the opinion of undergraduate and graduate EFL students towards Internet-based learning (Aydin, 2007; Slate, Manuel, \& Brinson, 2002; Usun, 2003) also found that the students generally had positive opinions towards Internet-based English learning/teaching.

\section{Conclusion}

Based upon the result of the present study, we found out that after Web-based reading strategy instruction, the experimental group performed better with regard to their reading tasks. Furthermore, the data obtained from questionnaires showed their higher level of improvement in reading strategy usage. Overall, the experimental group had positive attitudes towards Web-based reading strategy instruction.

The finding of the current study have made some valuable contributions towards the subject of integrating Web-based approaches into English pedagogy. A thorough look into the findings may clear these contributions.

The main focus of this study was exclusively on exposing the participants to appropriate reading strategies in comprehending English texts in a Web-based condition. First of all, many of the problems associated with reading comprehension were mainly related to lack of reading strategies knowledge, lack of easy access to interesting materials, and lack of flexibility in the use of some features (e.g., table of contents and indexes) 
automatically. So, it can be suggested that integrating Web-based approaches into instruction will unravel many problems that are related to reading comprehension.

Considering the findings of the present study may lead the readers to the great benefits of applying useful reading strategies in a Web-based environment with the aim of improving L2 learners' reading comprehension. The first consideration is that providing L2 learners with online materials enhances their motivation in progressing through different nodes of hypertexts. Moreover, a Web-based condition has the advantage of better time-management and provides L2 learners with authentic materials according to their needs and interest.

A wide range of Web-based environments will not only develop a better understanding of the learning process, but also changes L2 teachers' attitudes and behaviors in relation to advantages of integrating technology into instruction.

As the application of the Web-based program in teaching English is widespread, some implications are realized. There can be no doubt that in this new environment, both teachers and students will face some challenges. Clearly, this program provides a new way of teaching and learning. It is believed that integrating the Internet into the curriculum provides the most exciting and useful aid for L2 teachers and learners. Unlike standard linear texts, online texts present a new way to read in which the readers have many flexibilities.

In a Web-based program, there is still a dearth of research. The following suggestions, based largely on the results of this study, are proposed for future research. Firstly, replication of this study with different English proficiency levels is necessary in order to conclusively support the usefulness of a Web-based condition. Secondly, a comparative study of the learning achievement in the traditional condition and the Web-based condition should be carried out to find out the effectiveness of the study. Thirdly, a similar program can also carried out in distance Web-based condition in order to be compared with the traditional condition. We investigated the effects of Web-based instruction on teaching reading strategies; future research of this type should include other language skills (e.g., listening) and language components such as grammar and vocabulary. Moreover, the participants in the present study were tested for their hypertext and paper-based reading comprehension conditions to determine the effect of the Web-based program. It would be interesting to investigate how long this program is retained. Future research should, therefore, use a delayed posttest (e.g., one month after the training) to investigate the retention of the learning program, if any. In addition, L2 learners' attitudes towards applying reading strategies in a Web-based condition are also worth investigating in order to provide clear insights for materials developers.

\section{References}

Aebersold, J. A., \& Field, M. L. (1997). From reader to reading teacher: Issues and strategies for second language classrooms. New York: Cambridge University Press

Allen, D. (1992). Oxford placement test. Oxford: Oxford University Press.

Anderson, N. J. (1991). Individual differences in strategy use in second language reading testing. Modern Language Testing, 175, 460-472. http://dx.doi.org/10.1111/j.1540-4781.1991.tb05384.x

Anderson, J. R. (1993). Problem solving and learning. American Psychologist, 48(1), 35. http://dx.doi.org/10.1037/0003-066X.48.1.35

Anderson, N. J. (2002). The role of metacognition in second language teaching and learning. Washington: ERIC Digest.

Anderson, N. J. (2003). Scrolling, clicking, and reading English: Online reading strategies in a second/foreign language. The Reading Matrix, 3(3), 1-33.

Aydın, S. (2007). Gender effect on the writing quality of pen-paper and computer samples of EFL learners. Journal of Graduate School of Social Sciences of Balikesir University, 17(1), 120-127.

Barnett, M. A. (1989). More than meets the eye: Foreign language reading: Theory and practice (language in education). Englewood Cliffs: Prentice-Hall Regents.

Berge, Z. L., \& Collins, M. P. (Eds.). (1995). Computer-mediated communication and the online classroom: Volumes 1-3. Cresskill, NJ: Hampton Press.

Bernhardt, E. (2005). Progress and procrastination in second language reading. Annual Review of Applied Linguistics, 25, 133-150. http://dx.doi.org/10.1017/s0267190505000073

Boling, E. (2008). Learning from teachers' conceptions of technology integration: What do blogs, instant messages, and 3D chat rooms have to do with it? Research in the Teaching of English, 43(1), 74-100. 
Chifari, A., Chiazzese, G., Lucaiano, S., Merlo, G., Ottaviano, S., \& Allegra, M. (2010). A reflection on some critical aspects of online reading comprehension. Informatica, 7, 491-495.

Chinwonno, A. (2001). A comparison of Thai and English reading comprehension strategies of preservice teachers in Thailand. Unpublished doctoral dissertation, Ohio University.

Chou, C. T. (1992). Reading comprehension strategies and computer-assisted English language learning. Research Report (NSC 81-0301-H003-11). Taipei, Taiwan, ROC: National Science Council.

Coady, J. (1997). L2 vocabulary acquisition through extensive reading. In J. Coady, \& T. Huckin (Eds.), Second language vocabulary acquisition (pp. 225-237). Cambridge, UK: Cambridge University Press.

Coiro, J. (2003). Reading comprehension on the Internet: expanding our understanding of reading comprehension to encompass new literacies. The Reading Teacher, 56(5), 458-464.

Coiro, J., \& Dobler, E. (2007). Exploring the online reading comprehension strategies used by sixth - grade skilled readers to search for and locate information on the Internet. Reading Research Quarterly, 42(2), 214-257. http://dx.doi.org/10.1598/RRQ.42.2.2

Cunningham, C. A. (1999, October). Significance of the Internet for education. Paper presented at the C.A.P.E. Planning Group. Retrieved October 6, 2014, from http://webinstituteforteachers.org/talks/cape10-9.htm

Dail, J. S. (2004). Reading in an online hypertext environment: A case study of tenth-grade English student. Unpublished doctoral dissertation, Florida State University, 2003). Dissertation Abstracts International, 65(7), 2005.

Dubin, F., \& Bycina, D. (1991). Academic reading and the ESL/EFL teacher. Teaching English as a Second or Foreign Language, 2, 195-209.

Easton, S. (2003). Clarifying the instructor's role in online distance learning. Communication Education, 52(2), 87-105. http://dx.doi.org/10.1080/03634520302470

Ferdig, R. E. (2005). Towards implementing technologies in education: Exploring the pedagogy and people of good innovations. The Turkish Online Journal of Educational Technology, 4(2), 35-43.

Ganderson, R. (1998). New strategies for a new medium? Observing L2 reading on the World Wide Web. Retrieved October, 20, 2014 from http://www.oncalljournal.com

Grabe, W. (1991). Current developments in second language reading research. TESOL Quarterly, 375-406. http://dx.doi.org/10.2307/3586977

Grabe, W. (1999). Developments in reading research and their implications for computer-adaptive reading assessment. Issues in Computer-Adaptive Testing of Reading Proficiency, 10, 11-47.

Grabe, W. (2009). Reading in a second language: Moving from theory to practice. Cambridge: Cambridge University Press.

Huang, H., Chern, C., \& Lin, C. (2009). EFL learners' use of online reading strategies and comprehension of

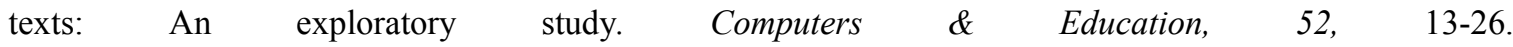
http://dx.doi.org/10.1016/j.compedu.2008.06.003

Kang, M. L. (2000). EFL: Computer-assisted reading instruction. Retrieved January 1, 2015 from the World Wide Web http://www.aare.edu.au/04pap/lim04139.pdf

Keep, C., McLaughlin, T., \& Parmer, R. (2000). The electronic labyrinth. Retrieved February 2, 2014, from http://www.iath.virginia.edu/elab/elab.html

Konishi, M. (2003). Strategies for reading hypertext by Japanese ESL learners. The reading matrix, 3(3), 20-35.

Krashen, S. (2003). Explorations in language acquisition and use: The Taipei lectures. New York: Heinemann.

Leu Jr., D. J. (2002). The new literacies: Research on reading instruction with the Internet. What Research Has to Say About Reading Instruction, 3, 310-336. http://dx.doi.org/10.1598/0872071774.14

Leu, D. J. Jr, Kinzer, C. K., Coiro, J., \& Cammack, D. W. (2004). Towards a theory of new literacies emerging from the Internet and other information and communication technologies. In N. R. B. Ruddell, \& N. Unrau (Eds.), Theoretical models and processes of reading (5th ed., pp. 1570-1613). Oxford: Oxford University Press.

Lin, H., \& Chen, T. (2006). Decreasing cognitive load for novice EFL learners: Effects of question and descriptive advance organizers in facilitating EFL learners' comprehension of an animation-based content lesson. System, 34, 416-431. http://dx.doi.org/10.1016/j.system.2006.04.008 
Mason, R. (1991). Moderating educational computer conferencing. Matrix, 3, 97-119.

Namphadorn, W. (2007). Enhancing students' strategies for reading comprehension through a call program. Unpublished master's thesis, Graduate School, Khon Kaen University.

National Reading Panel. (2000). Report of the National Reading Panel: Teaching children to read. Retrieved February 20, 2014, from http://www.nationalreadingpanel.org/publications/subgroups.htm

O'Malley, J. M., \& Chamot, A. U. (1990). Learning strategies in second language acquisition. Cambridge: Cambridge University Press. http://dx.doi.org/10.1017/CBO9781139524490

Oxford, R. L. (1990). Language learning strategies: What every teacher should know. New York: Newbury.

Oxford, R. L. (2001). Language learning strategies. In R. Carter, \& D. Nunan (Eds.), The Cambridge guide to teaching English to speakers of other languages (pp. 166-172). New York: Cambridge University Press. http://dx.doi.org/10.1017/CBO9780511667206.025

Paran, A. (1996). Reading in EFL: Facts and fictions. English Language Teaching Journal, 50(1), 25-34. http://dx.doi.org/10.1093/elt/50.1.25

Paulsen, M. P. (1995). Moderating educational computer conferences. In Z. L. Berge, \& M. P. Collins (Eds.), Computer-mediated communication and the online classroom in distance education (pp. 81-90). Cresskill, NJ: Hampton Press.

Pitchayapa, C. (2008). Assessing reading strategy training using a call-based approach for Thai EFL students' English hypertext reading. Unpublished master's thesis, Suranaree University of Technology.

Rand Reading Study Group. (2002). Reading for understanding: Towards an R\&D program in reading comprehension rand, Santa Monica. Retrieved July 22, 2014, from http://www.rand.org/multi/achievementforall/reading/readreport.html

Salmeron, L., Canas, J. J., Kintsch, W., \& Fajardo, I. (2004). Reading strategies and hypertext comprehension: Research department in experimental psychology. Spain: University of Granada

Salmon, G. (2000). E-moderating: The key to teaching and learning online. London: Koganage. $\mathrm{http}: / / \mathrm{dx}$. doi.org/10.4324/9780203465424

Schwartz. (1984). Measuring reading competence: A theoretical perspective approach. New York: Plenun Press. http://dx.doi.org/10.1007/978-1-4899-0387-7

Shelton, M. W., Lane, D. R., \& Waldhart, E. S. (1999). A review and assessment of national educational trends in $\begin{array}{llll}\text { communication instruction. } \quad \text { Communication } & \text { Education, } 228-237 .\end{array}$ http://dx.doi.org/10.1080/03634529909379171

Simthamnimit, S. (2004). A construction of call on reading comprehension in English. Unpublished master's thesis, Khon Kaen University, Thailand.

Singhal, M. (2001). CALL for reading skills in English: An interactive web program for college-level ESL students. Retrieved from February 14, 2014, from http://elc.polyu.edu.hk/conference/papers2001/singhal.htm

Slate, J. R., Manuel, M., \& Brinson, K. (2002). The "digital divide": Hispanic college students' views of educational uses of the Internet. Assessment and Evaluation in Higher Education, 27(1), 75-93. http://dx.doi.org/10.1080/02602930120105081

Soonthornmanne, R. (2002). The effect of the reciprocal teaching approach on the reading comprehension of EFL students. RELC Journal, 33, 125-141. http://dx.doi.org/10.1177/003368820203300206

Suwanabubpha, S. (2006). Content-based language learning software on Kamma. Unpublished doctoral dissertation, Suranaree University of Technology, Thailand.

Thanasuntornrerk, B. (2004).The development of English reading lessons in science and technology for English I students at Suranaree University of Technology. Unpublished doctoral dissertation, Suranaree University of Technology, Thailand.

Theodorou, E. (2006). Comparing the effects of learning the structure strategy via Web-based training or classroom training on the recall of near and far transfer texts. Unpublished doctoral dissertation, Pennsylvania State University.

Usun, S. (2003). Educational uses of the Internet in the world and Turkey: A comparative review. Turkish Online 
Journal of Distance Education, 4(3), 25-35.

Vaughan, J. L. (1984). Assessing reading: Using cloze procedure to assess reading skills. ERIC Document Reproduction Service, 7, 314-646.

Wallace, R. M. (2003). Online learning in higher education: A review of research on interactions among teachers and students. Education, Communication, and Information, 3(2), 241-280. http://dx.doi.org/10.1080/14636310303143

Wolf, D. F. (1993a). Issues in reading comprehension assessment: Implications for development of research instruments and classroom tests. Foreign Language Annals, 322-331. http://dx.doi.org/10.1111/j.1944-9720.1993.tb02289.x

Wolf D. F. (1993b). A comparison of assessment tasks used to measure. FL Reading Comprehension Modern Language Journal, 473-489.

\section{Copyrights}

Copyright for this article is retained by the author(s), with first publication rights granted to the journal.

This is an open-access article distributed under the terms and conditions of the Creative Commons Attribution license (http://creativecommons.org/licenses/by/3.0/). 